\title{
GaAs/AlGaAs и InGaAs/AlGaAs гетероструктуры для полупроводниковых инфракрасных излучателей
}

\author{
Д.В. Гуляев ${ }^{1}$, Д.В. Дмитриев ${ }^{1}$, Д.Ю. Протасов ${ }^{1,2}$, Н.В. Фатеев ${ }^{1}$, А.С. Кожухов ${ }^{1}$, К.С. Журавлев ${ }^{1}$ \\ ${ }^{1}$ Институт физики полупроводников им. А.В. Ржанова СО РАН, Новосибирск, \\ 630090, пр. Лаврентьева, 13 \\ ${ }^{2}$ Новосибирский государственный технический университет, Новосибирск, 630073, пр. Карла \\ Маркса, 20 \\ тел:+7 (383) 330-4475, факс:+7 (383) 333-2771, эл. почта: gulyaev@isp.nsc.ru
}

DOI 10.34077/RCSP2021-93

В данной статье мы приводим результаты работы по получению методом молекулярно-лучевой эпитаксии гетероструктур с квантовыми ямами (КЯ) GaAs/AlGaAs и InGaAs/AlGaAs, предназначенных для создания на их основе светодиодов для работы в ближнем ИК диапазоне. Исследовано влияние ростовых условий гетероструктур, выращенных методом молекулярно-лучевой эпитаксии и постростового отжига на квантовый выход гетероструктур. Внутренний квантовый выход был определен из люминесцентных данных в рамках стандартной АВС модели, учитывающей излучательную рекомбинацию, безызлучательную рекомбинацию Шокли-Рида и Оже-рекомбинаци [1]. Дополнительно квантовый выход был оценен из сравнения интенсивностей ФЛ образцов с ФЛ радомина 6G, обладающим на длине волны 527 нм квантовым выходом около 96\%. Полученные данные с точностью до нескольких процентов совпали с данными, полученными из анализа мощностной зависимости ФЛ.

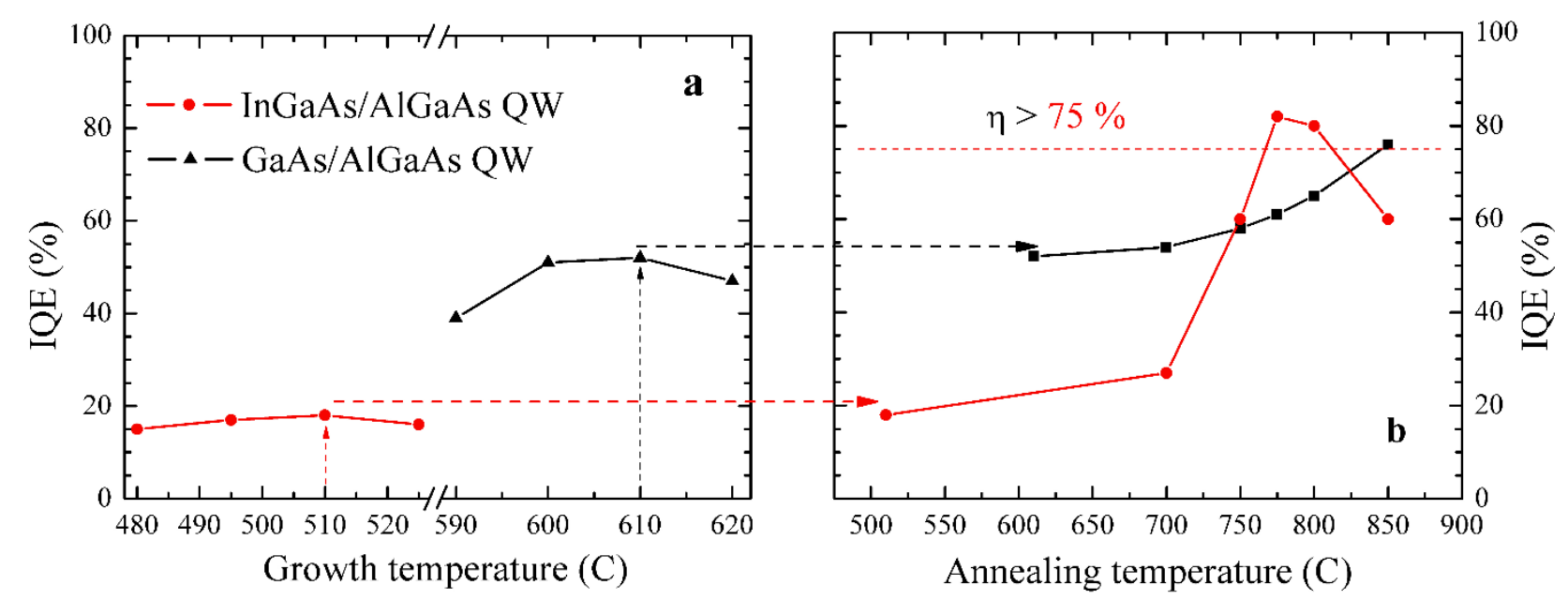

Рисунок 1. Зависимость внутреннего квантового выхода люминесценции гетероструктур с InGaAs/AlGaAs и GaAs/AlGaAs КЯ от (a) ростовой температуры и (b) температуры отжига. Мощность лазерного возбуждения 20 мВт.

Показано, что совокупной оптимизацией условий роста и пост-ростового отжига удается достичь квантового выхода люминесценции как GaAs/AlGaAs ГЭС, так и InGaAs/AlGaAs структур в 75-80 \% при умеренной мощности накачки (см. рис. 1).

\section{Лuтература}

[1] Yang-Seok Yoo, Tae-Moo Roh, Jong-Ho Na, Sung Jin Son, and Yong-Hoon Cho // Appl. Phys. Lett. 2013. т. 102, вып.21, С.211107-1-5. 